地学雑誌 84，5 (1975)

\title{
道路網の階層化システム
}

一一静岡西部地域の例—

\author{
土井重彦 \\ The Ordering System for Road Networks in the Western Part \\ of Shizuoka Prefecture in Central Japan-An Example
}

\author{
Shigehiko DoI
}

\begin{abstract}
The purpose of the present paper is to design the ordering system for complex road networks in a region. The system design is based on fundamental spatial patterns of central settlements as traffic generators, and trafflc flows. The ordering algorithm in detail is as follows: (1) given road networks; (2) identification of central settlements and construction of the hierarchy; (3) division of given networks into central settlementroad networks; (4) transformation of circuited networks to trees; (5) linkage ordering; (6) superimposition of ordered linkages and output finally ordered road networks in a region.

An application of the system was made for road networks in the western part of Shizuoka Prefecture in Central Japan. And their flow properties on ordered road networks in Aratama area and Fukude area in this region were investigated. As the results, it has become clear that the order was closely conformed with flow properties: that is, compared with low order networks, high order networks have the properties that traffic volume is more, trip-length is longer, speed is higher, essential traffic means are not walk nor bicycle but motor vehicle, and trip-purpose is limited to bussiness and work. This system is applicable to the case of road networks which are bundled centralized flows, and is useful to categorize local and regional road networks which lack flow data.
\end{abstract}

最近の交通地理学の研究は地域の空間的組織, つまり空間的構造と空間的過程を解明する一側面として 進められている。その多くは交通網に関するものであり, とりわけその連結性と結節点の相対的近接性を 測定し，評価するといつた網全体および結節点の諸性質の分析に焦点をあてている。しかし，交通網の一 方の構成要素である連鎖線の性質に関する分析は上記の 2 分析と同様に重要であるにもかかわらず，ほと んぞなされていない。この分析に基礎を与えるのは，交通網内での連鎖線の相対的重要性を測定，あるい はそれを階層的に分類することであると考える。それによつて連鎖線に関連した一連の分析が計量的に処 理可能となろう。

このような階層的分類のシステム化はいくつか試みられている。たとえば, WALLACE (1958), KIS-

財団法人 日本システム開発研究所 
SLING (1969)，アメリカ合衆国交通局 (1969), 建設省 (1972) 等がある。それらはいずれも複雑な交通流 のデータと計算を要求しており, 実際には非常に困難な問題をともなつているのが常である。ところで, 地形学, 水文学で用いられている水流次数化システム（栕根, 1973）を直接的に応用することによつて, 比較的単純交通網の連鎖線を階層的に分類することが可能となることを示したのが HAGGETT (1967) と RIDDELL (1973) である。それらはいずれも強力な単一の結節点に着目しての分類システムである。 しかし，実際の交通網は水系網に比べて，いつそう複雑であり，複数の結節点を持つている。

そこで, 本論では水流次数化システムをさらに拡大することによつて, 複数の結節点を含んだ地域的道 路網の連鎖線を階層的に分類するシステムを提示する。また，このシステムを実証する意味で，階層化さ れた連鎖線と交通流の関係を，静岡西部地域の道路網を例に述べることにする。

\section{I. 道路網の階層化システム}

\section{1. 仮定}

ある地域において，交通を発生，集中させるのは中心地機能が集穦した場所，すなわち中心的集落であ るとまず仮定する。この中心的集落の分布は一般的に階層型をとる (CHRISTALLER, 1933)。つまりそそ れが中心地機能の集積度合によつて，いくつかの階層に区分されるのである。また，中心的集落間の交通 流の空間的パターンは一般的に（1）ブロック，(2) 後背地，（3）階層型の 3 性質を有している（HAY， 1973)。

地域の道路網体系はこのような交通流の空間的パターンに追随して，それらをたばねて流す施設体系で ある。当然, それは階層体系をとる。つまり, 小中心的集落から中中心的集落への交通に供する道路網上 の流れと, 大中心的集落へのそれとは自ずと性質を異にしている。この性質が交通量, トリップ長（起終 点間の移動距離), 交通速度, 交通機関, 交通目的で規定されるものとすると, 下位の道路網ほど, 交通 量は少く, トリップ長は短く, 交通速度はそう要求されなく, 徒歩, 自転車等が重要な交通機関で, 多目 的な交通に供しているといえる。逆に, 上位の道路網ほど, 交通量が多く, トリップ長は長く, 交通速度 が要求されるため自動車が主要な交通機関となり，限られた目的の交通に供することになる。

このような道路網上の交通流の性質に違いが生ずるのは, とりもなおさず交通発生・集中漂としての中 心的集落のもつ中心地機能とそのサービスの到達距離, 方向の違いによるものである。以下, この点に着 目して，仮想的地域における道路網を階層的に分類する手順・システムを示す。その際，使用する基本的 概念は近接性と最短経路である。

\section{2. 手順}

1）中心的集落の確認とその階層化

まず，分類しょうとする道路網を与える。ついで，その道路網上に中心的集落を見付け，それを類型化 し，階層的に分類するのである。この中心的集落の確認とその階層化の便宜的方法にはいろいろある。た とえば, 人口規模, 交通の起終点における発生, 吸収量によるもの等である。

第 1 図に示すような仮想的地域において，与えられた道路網上に，上記のいずれかの方法を用いて，17 の中心的集落が確認されたとする。また，それらは1つの上位中心，1つの中位中心，3つの下位中心， 12の最下位水心に階層区分されるものとしょう（第1図 A, B , C)。

2) 中心的集落一道路網の構成

つぎの手順は与えられた道路網を，各中心的集落の機能が影響を及ぼす道路網に分割することである。 これを中心的集落一道路網という。これを設定するために用いる概念は近接性である。そうすると，中心 的集落一道路網はつぎのように定義づけられる。ある中心的集落 $\mathrm{P}_{1}$ が他の $\mathrm{P}_{2}, \mathrm{P}_{3}, \cdots \mathrm{Pn}$ より近接しや すい道路網の部分を $\mathrm{P}_{1}$ の中心的集落一道路網とする。この中心的集落一道路網は中心的集落の階層に対 応して，階層型を構成する。 

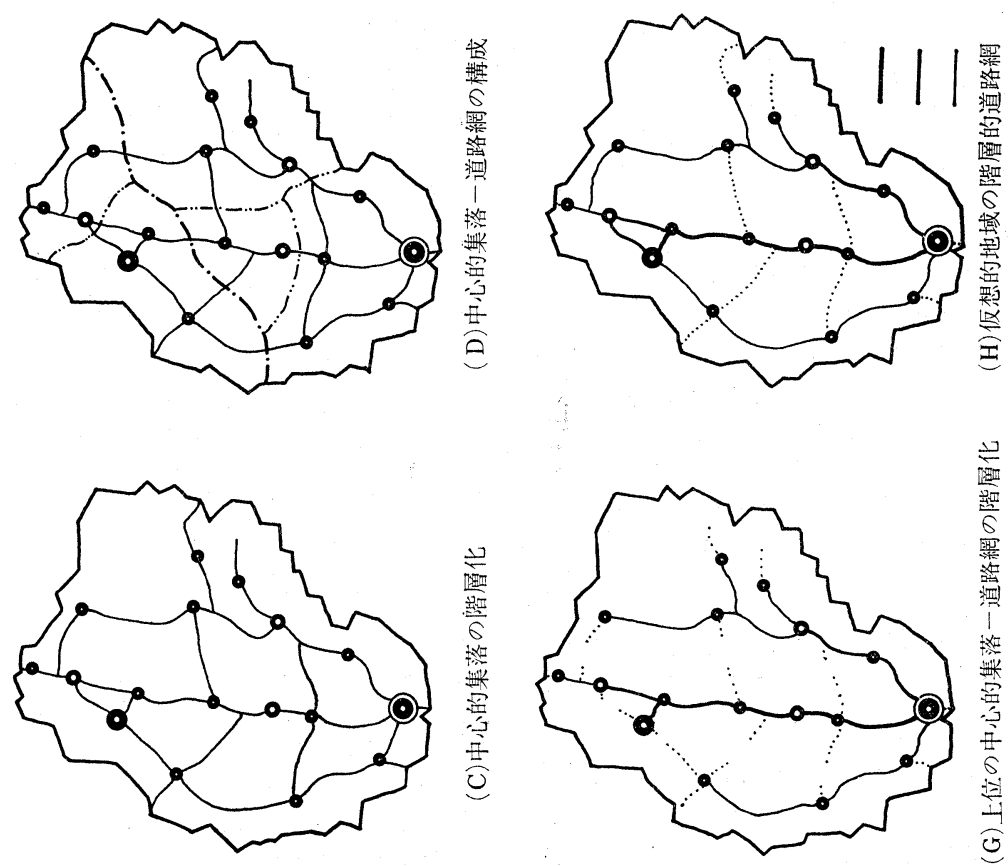

(1)
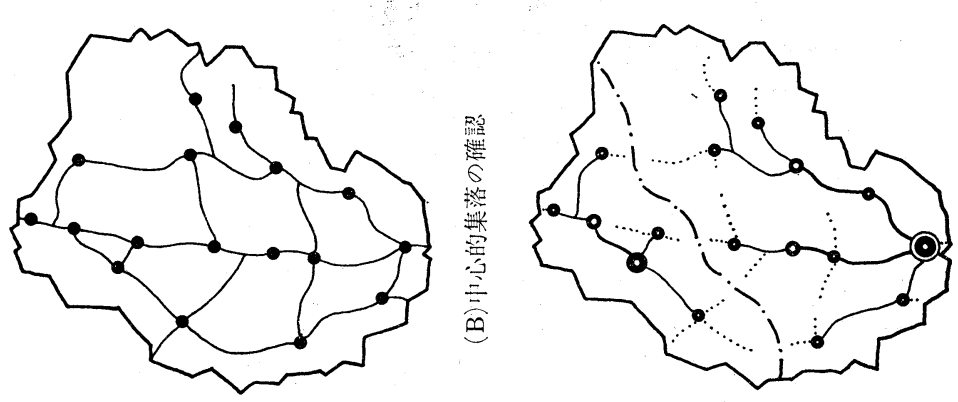

京

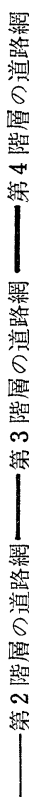

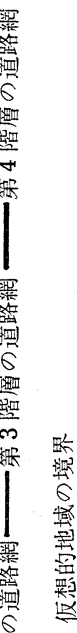

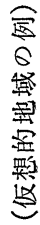

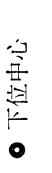

然

菑

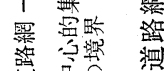

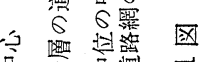

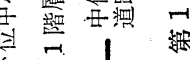

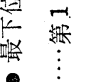

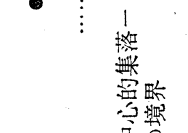

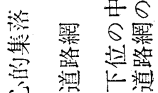

\begin{tabular}{l|l}
1 \\
-
\end{tabular}

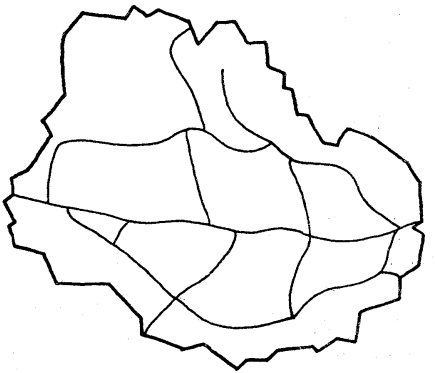

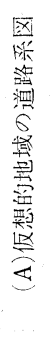

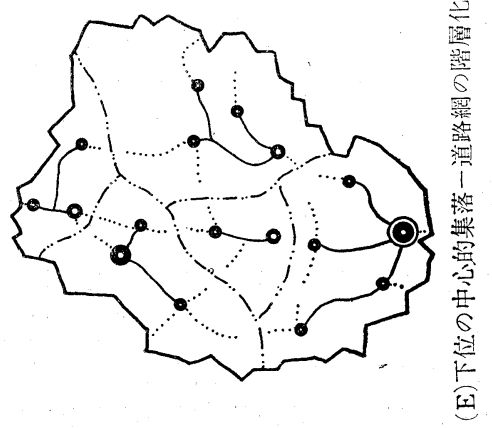

宰 
この近接性は距離，時間，費用等で測定することができる。また，中心的集落への近接は人閒の行動に 関するものであるから，中心的集落一道路網を，逆に中心的集落の機能のサービス圈域あるいは領域であ るとして設定することも可能である。

この仮想的地域では，中心的集落一道路網を上記のいずれかの方法で設定してみると，1つの上位の中 心的集落一道路網，2つの中位のそれ，5つの下位のそれ，17の最下位のそれに分割され，階層型を構成 することになる(第1 図D)。

3） 道路網の樹状構造化

一般的に，中心的集落一道路網は回路を含んだ構造，つまり回路化網である。そこで，つぎの手順は分 割された中心的集落一道路網を樹状網の構造に変化することである。

ある階層の中心的集落一道路網において，任意の地点から中心的集落へ向う経路はいくつか考えられ る。そこで，中心的集落から代替的経路上に近接性が等しくなる地点，分岐点をまず確認する。この地点 を確認することによつて，考えられた中心的集落への最短経路を形成する樹状構造に回路化構造を交換す ることができる。

このような交換を，仮想的地域の全ての中心的集落一道路網についておこなう。

4) 道路網の階層化

つぎに，樹状構造に交換された道路網の連鎖線を階層化する。つまり，各連鎖線をその性質で分類し， 次数化するのである。この場合，つぎのような前提を与えておこう。連鎖線の階層の変換点，すなわち個 々の道路網上の交通流の性質が変わる地点を中心的集落であるとし，階層的に上位の中心的集落を通過す るにしたがつて1階層づつあげることにする。

たとえば，仮想的地域における下位の中心的集落一道路網を階層化してみよう。この場合，樹状構造化 した道路網の末端から下位中心向う道路網上に最下位中心が存在すると, 最下位中心までを第 1 階層の 連鎖線とし，そこから下位中心までのそれを第 2 階層とする。このような階層化を下位，中位，上位の全 ての中心的集落一道路網についておこなう。それぞれの結果を示したのが第 1 図 E Gである。

最後に, これらを総合化して, 最終的に各連鎖線の階層を決定するのである。総合化する方法は各階層 ごとの中心的集落一道路網の階層化の結果を重ね合せ，ある連鎖線の階層が異つている場合には高次の階 層を採用することにする。

この仮想的地域での最終的な道路網の階層化の結果は第 1 図Hとなる。ここでは 4 階層に道路網の連鎖 線を分類することができる。すなわち，第 1 階層は下位中心，第 2 階層は最下位中心，第 3 階層は中位中 心，第 4 階層は上位中心のサービスを享受するためにたばねた交通を流す道路網である。

以上の手順によつて，道路網の連鎖線をその交通流の性質で，階層的に分類あるいは相対的重要性を分 析的に測定することができる。しかし，このシステムは地域的道路網上の交通流を閉システムであると仮 定した上でのものである。実際には，地域を通過したり，他地域との交通もあるため，それを開システム として取り扱わなけれなら奴あう。そこで, この手順で出力された結果は経験的に修正を加える必要 がある。

\section{II. 静岡西部地域の道路網の階層化とその交通流特性}

\section{1. 道路網の階層化}

本節では, 前章の手順にしたがつて, 静岡西部地域の道路網を階層的に分類してみる。特に, 静岡西部 地域を選んだのは，それが日本列島の中央部に位置し，極めて標準的な交通流パターンを示していると考 えたからに他ならない。そこで, まずこの地域の全道路網を与える。ついで, この道路網上の中心的集落 の確認と，その階層化であるが，ここでは「静岡西部地方生活圈整備計画調查」(建設省，昭和44年）に むとずいて，つぎのような 4 階層の中心的集落を設定することにする。

上位中心 : 浜松市の人口集中地区, 


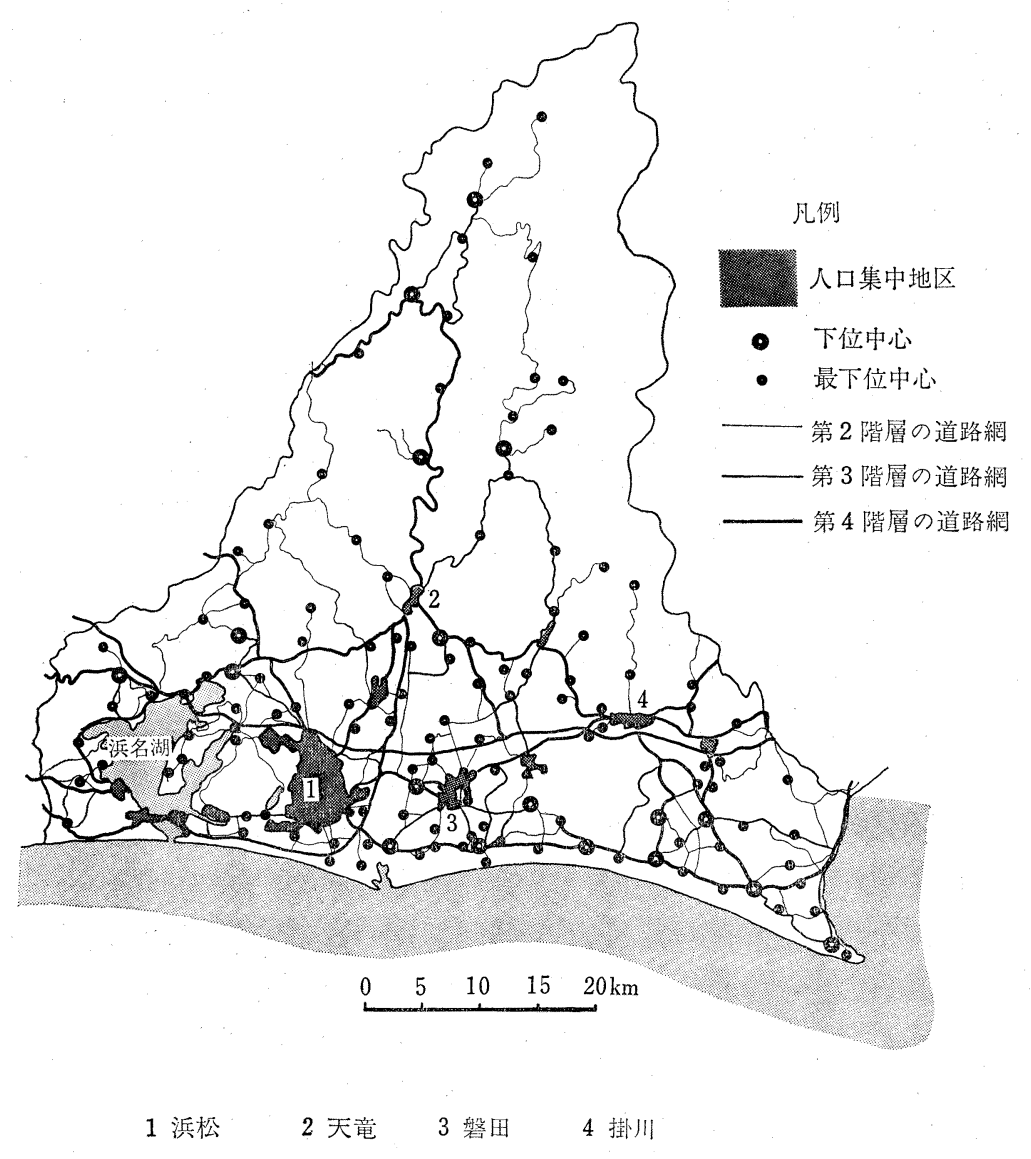

第 2 図静岡西部地域の階層的道路網

中位中心: 天竟, 箬田, 掛川の各市の人口集中地区

下位中心 : 湖西, 浜北, 袋井, 佐久間, 浜岡, 水䆶, 竜山, 春野, 森, 鄷岡, 相良, 御前崎, 小笠, 城

東, 大須賀, 浅羽, 福田, 竜洋, 豊田, 引佐, 三ヶ日, 細汇, 可美, 雄踏, 舞坂, 新居の各市町村の

人口集中地区または中心集落,

最下位中心 : 129の最下位領域の中心的集落,

つぎに, 中心的集落一道路網の構成であるが，ここではやはり前述の調査で設定されている各中心の領 域をそのまま採用することにする。そうすると, この地域の道路網を, 1 つの上位の中心的集落一道路 網，4つの中位のそれ，31の下位のそれ，160の最下位のそれに分割することができる。

このような各々の中心的集落一道路網を樹状構造に変換するのがつぎの手順である。ただし，この場 合, 近接性の測定には道路距離を用いることにする。そして, 最下位中心を第 2 階層, 下位中心を第 3 階 層, 中位中心を第階層の道路網への変換点として, 樹状構造化した全ての中心的集落一道路網の階層化を おこなら。

この結果を重致合せて，最終的なこの地域の道路網を階層的に分類したのが第 2 図である。ただし，こ の図は通過交通，およびこの地域の上位中心と隣接諸地域の上位中心間の交通に供する道路網はすへて第 4 階層のそれとして組み入れて, 修正したものである。

2. 交通流の調查とデータ 
本節では，前節で階層的に分類した道路網上を流れる交通の性質について調査した結果を示めす。この 地域の道路交通流に関する唯一の統計的資料は静岡県一般交通調查統計（昭和46年）である。この資料か らは行政分類上の県道以上の道路網の交通量, とりわけ自動車交通量のみしか取り出すことができない。 そこで，他のデータを得るために調査を実施した。

この調査は, 住民の 1 日の行動と道路利用状況を把握することを目的として, この地域の浜北市蝔王地 区と福田町を選定して実施したものである。前者は最下位中心の領域, 後者は下位中心の領域を対象とし た。しかし，それはいずれも完全に領域全域にわたるものでなく，著しく自然的条件の制約を受けている と考えられる区域については調査対象からはずした。また，前者の調查実施日は昭和48年12月11日 (火), 後者のそれは昭和 49 年 2 月 20 日（水）である。そして，それぞれの領域において，世帯の $25 \%$ を標本とし て調查した。

この調査から得られたデー夕は第 1 表 第 3 表である。それはトリップ数, 交通機関, 交通目的を道路 網の階層別に示したものである。ただし，ここでのトリップとは人トリップをいい，人 1 人が自宅一目的 地間の往復を以て1トリップとする。また, トリップ長, 交通速度および通過交通流ならびに他領域から の流入交通流に関するデー夕はこの調查からは得られなかつた。

\section{3. 相関性に評価}

前節までの結果をもとに，ここではこの地域における階層別道路網の交通流の性質を比較してみること にする。

まず，この地域全域の階層別道路網の平均自動車交通量をみると，第 4 階層の道路網は 4,130 台/12時 間, 第 3 階層は 2,956 台/12時間, 第 2 階層 1,711 台/12時間, 第 1 階層1,323台/12時間である。これは明白 に道路網の階層が順次下がるにしたがつて，自動車交通量が少なくなることを示している。

また，調査対象領域の道路網について，平均トリップ数で，その交通量をみると，㢈玉地区では，第 4 階層のそれは88.9トリップ数/日, 第 2 階層149.1トリップ数/日, 第 1 階層15.1トリップ数/日である（第 1 表)。ただし，第 3 階層のそれが不明なのは，この地区にこれに該当する道路網が存在していないため である。また，第 4 階層のトリップ数が第 2 階層のそれよりかなり少ないのは通過および流入トリップが 除外されているためであると考えられる。福田町のそれは, 第 4 階層188.8トリップ数/日，第 3 階層 164.4 トリップ数/日, 第 2 階層90.3トリップ数/日, 第 1 階層64.3トリップ数/日とやはり道路網の階層が下が るにしたがつてトリップ数が少なくなつている(第 1 表)。これらのことから，階層が上位の道路網ほど交 通量が多く，下位の道路網ほどそれが少ないといえる。

つぎに，階層別道路網において，何にが主要な交通機関であるかをみる。ここでは，交通機関別にトリ ップ数一道路延長指標 $\left(\sum_{\mathrm{i}=1}^{\mathrm{n}} \mathrm{Ti} \cdot \mathrm{Li} ; \mathrm{Ti}: \mathrm{i}\right.$ 区間の平均トリップ数, $\mathrm{Li}: \mathrm{i}$ 区間の道路延長) の道路網の 階層別構成比を比較することによつて，それを相対的に把握する。

さて，㞕玉地区についてみると，通過トリップに供すると考えられる第 4 階層の道路網は除外するとし て，第 2 階層のそれはバス $(74.5 \%)$, 自動車 $(40.6 \%)$, 第 1 階層はオートバイ $(66.0 \%)$, 自転車 $(64.6$ $\%)$, 徒歩 $(58.0 \%$ ) といつた交通機関が主体となつている（第 2 表A）。そして，第 2 階層と第 1 階層の道 路網間に注明白な主体的交通機関の相違がみられる。福田町の場合, 第 4 階層の道路ではバス $(26.7 \%)$, 自動車 (25.8\%), 第 3 階層ではバス (57.2\%), 自動車 (22.1\%), 第 2 階層では自転車 $(21.2 \%)$, 徒歩 (20.9\%)，オートバイ (20.3\%)，第 1 階層では徒歩 $(69.2 \%)$ ，自転車 $(62.4 \%)$ ，オートバイ $(60.0 \%)$ が 主体的交通機関となつている (第 2 表B)。第 4 階層と第 3 階層, および第 2 階層と第 1 階層間には明白な 交通機関の差はみうけられないが，第 3 階層と第 2 階層間には瀝然たる差がみられる。

この 2 地区の考察から，階層的に上位の道路網の交通に供する主体的交通機関は自動車，バスであり， 下位のそれは徒歩，自転車である。また，この違いは交通速度に係るものであるから，当然上位の道路網 ほど交通速度が速く，下位のそれは遅いといえる。 
第 1 表 階層別道路網の交通量

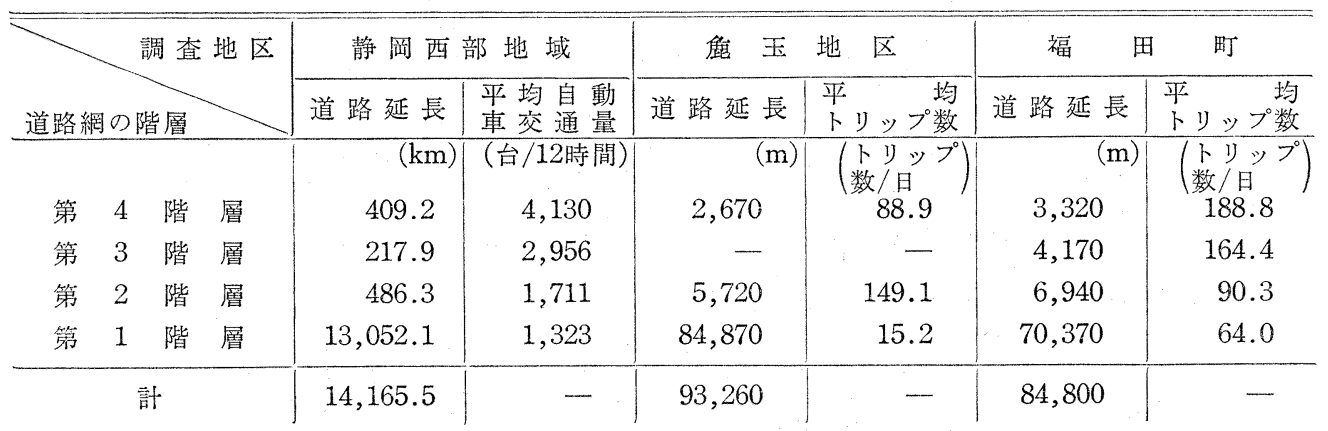

（A）㦄玉地区

第 2 表 階層別道路網の交通機関

\begin{tabular}{|c|c|c|c|c|c|c|c|c|}
\hline 道路網 & の階層 & 幾関 & 徒歩 & 自 転 車 & オートバィ & 自 動 車 & バ & 計 \\
\hline 第 & 4 階 & 層 & $\begin{array}{c}57,138 \\
(13.2)\end{array}$ & 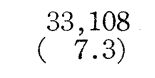 & $\begin{array}{c}24,030 \\
(\quad 8.2)\end{array}$ & $\begin{array}{c}118,815 \\
(10.9)\end{array}$ & $\begin{array}{c}4,272 \\
3.9)\end{array}$ & $\begin{array}{c}237,363 \\
(10.0)\end{array}$ \\
\hline 第 & 3 階 & 層 & $(-)$ & $(-)$ & $(-)$ & $(-)$ & $(-)$ & $(-)$ \\
\hline 第 & 2 階 & 層 & $\begin{array}{l}124,696 \\
(28.8)\end{array}$ & $\begin{array}{c}126,984 \\
(28.1)\end{array}$ & $\begin{array}{c}76,079 \\
(25.8)\end{array}$ & $\begin{array}{c}442,728 \\
(40.6) \\
\end{array}$ & $\begin{array}{c}82,368 \\
(74.5) \\
\end{array}$ & $\begin{array}{c}852,852 \\
(35.8) \\
\end{array}$ \\
\hline 第 & 1 階 & 層 & $\begin{array}{c}251,064 \\
(58.0)\end{array}$ & $\begin{array}{c}292,594 \\
(64.6)\end{array}$ & $\begin{array}{c}194,672 \\
(66.0)\end{array}$ & $\begin{array}{c}528,129 \\
(48.5)\end{array}$ & $\begin{array}{r}23,817 \\
(21.6)\end{array}$ & $\begin{array}{c}1290,276 \\
(54.2)\end{array}$ \\
\hline & 計 & & $\begin{array}{c}432,898 \\
(100.0)\end{array}$ & $\begin{array}{c}452,686 \\
(100.0)\end{array}$ & $\begin{array}{l}294,778 \\
(100.0)\end{array}$ & $\begin{array}{c}1,089,672 \\
(100.0)\end{array}$ & $\begin{array}{l}110,457 \\
(100.0)\end{array}$ & $\begin{array}{r}2,380,491 \\
(100.0)\end{array}$ \\
\hline
\end{tabular}

学位：トリップ数・m

( ) : \%

（B）福田町

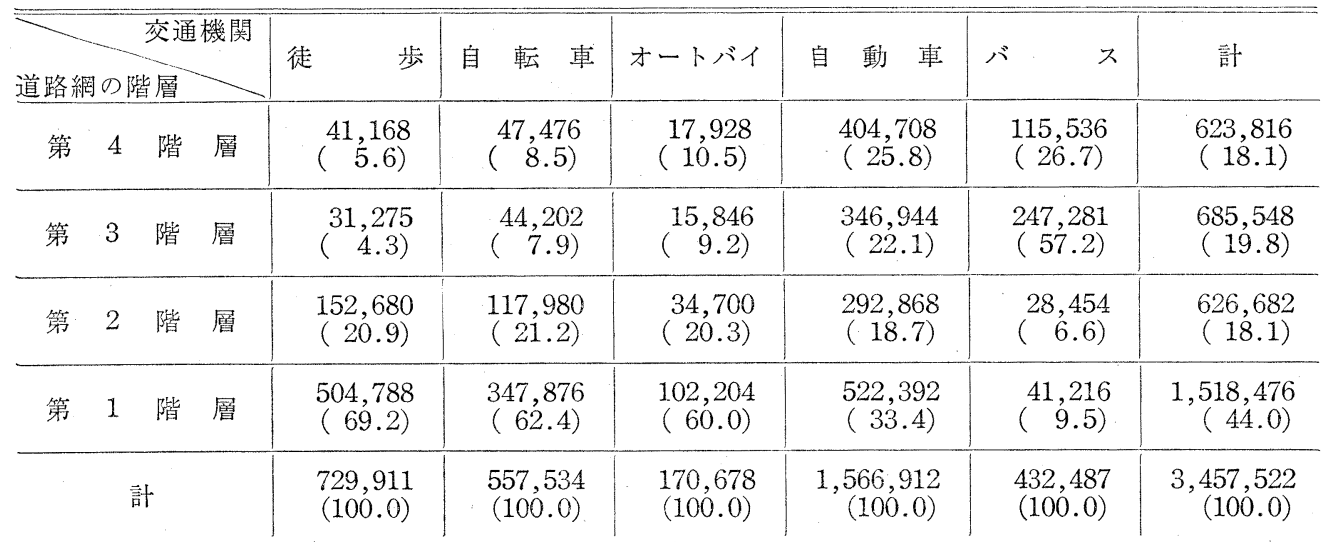

単位:トリップ数・m

( ) :\% 
（A）鹿玉 地 区

第 3 表 階層別道路網の交通目的

\begin{tabular}{|c|c|c|c|c|c|c|c|c|c|}
\hline \multicolumn{3}{|c|}{ 道路網の階層 } & 通学 & 勤 & 業 & 買 物 & 遊 & その他 & 計 \\
\hline 第 & 4 & 階 層 & $\begin{array}{r}42,720 \\
(\quad 8.9)\end{array}$ & $\begin{array}{r}43,521 \\
(\quad 6.6)\end{array}$ & $\begin{array}{c}98,790 \\
(14.2)\end{array}$ & $\begin{array}{r}29,637 \\
(\quad 8.3)\end{array}$ & $\begin{array}{l}8,544 \\
(11.6)\end{array}$ & $\begin{array}{c}14,151 \\
(12.2)\end{array}$ & $\begin{array}{c}237,363 \\
(10.0)\end{array}$ \\
\hline 第 & 3 & 階 層 & $(-)$ & $(-)$ & $(-)$ & $(-)$ & $(-$ & $(-\overline{)}$ & $\overrightarrow{(-)}$ \\
\hline 第 & 2 & 階 層 & $\begin{array}{c}167,024 \\
(34.8)\end{array}$ & $\begin{array}{c}279,708 \\
(42.5)\end{array}$ & $\begin{array}{c}222,508 \\
(32.0)\end{array}$ & $\begin{array}{c}118,404 \\
(33.2)\end{array}$ & $\begin{array}{c}17,160 \\
(23.4)\end{array}$ & $\begin{array}{c}48,048 \\
(41.3)\end{array}$ & $\begin{array}{c}852,852 \\
(35.8)\end{array}$ \\
\hline 第 & 1 & 階 層 & $\begin{array}{c}269,490 \\
(56.3)\end{array}$ & $\begin{array}{c}336,144 \\
(50.9)\end{array}$ & $\begin{array}{c}373,642 \\
(53.8)\end{array}$ & $\begin{array}{c}209,106 \\
(58.5)\end{array}$ & $\begin{array}{r}47,723 \\
(65.0)\end{array}$ & $\begin{array}{c}54,171 \\
(46.5)\end{array}$ & $\begin{array}{c}1,290,276 \\
(54.2)\end{array}$ \\
\hline & & & $\begin{array}{c}479,234 \\
(100.0)\end{array}$ & $\begin{array}{c}659,373 \\
(100.0)\end{array}$ & $\begin{array}{c}694,940 \\
(100.0)\end{array}$ & $\begin{array}{r}357,147 \\
(100.0)\end{array}$ & $\begin{array}{r}73,427 \\
(100.0)\end{array}$ & $\begin{array}{c}116,370 \\
(100.0)\end{array}$ & $\begin{array}{c}2,380,491 \\
(100.0)\end{array}$ \\
\hline
\end{tabular}

単位：トリップ故・m

( ) : \%

（B）福田町

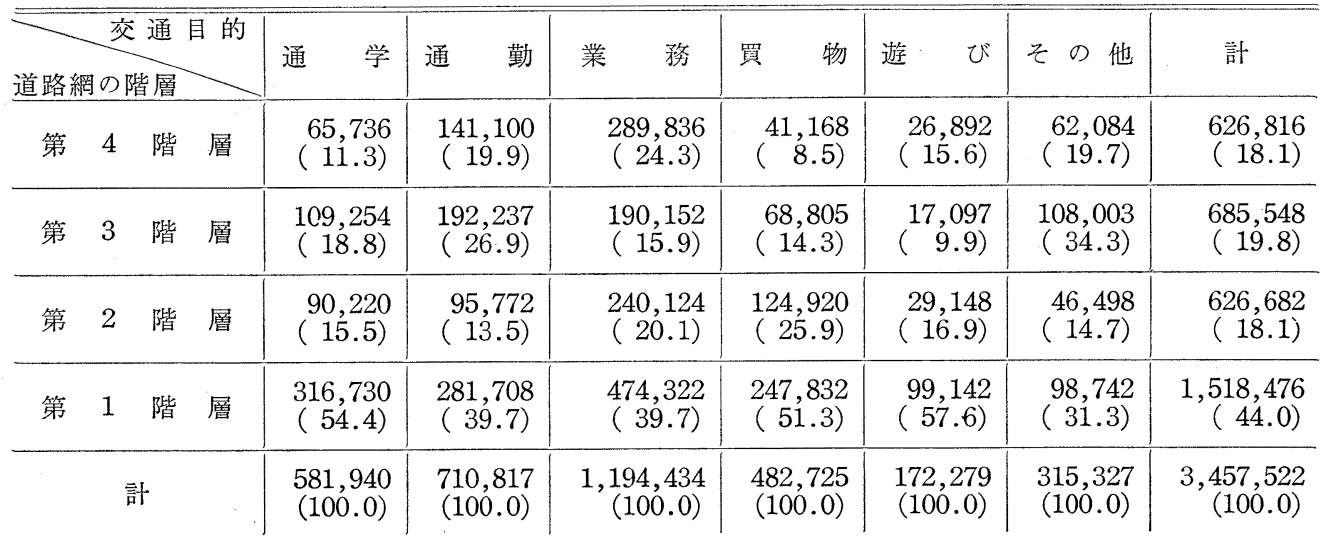

単位：トリップ故・m

( ) : \%

同じようにトリップ数一道路延長指標の構成比を用いて，階層別道路網の主体的交通目的をみる。鹿玉 地区では，第 4 階層の道路網は業務 (14.2\%)，第 2 階層は通勤 (42.5\%), 通学 (34.8\%), 買物 (33.2\%), 業務 (32.0\%)，第 1 階層は遊び(65.0\%)，買物 (58.5\%)，通学 (56.3\%)，業務 (53.8\%)，通勤 (50.9\%)を 目的とした交通に供している(第 3 表A)。福田町についてみると，第 4 階層の道路網では業務 $(24.3 \%)$, 第 3 階層では通勤 (26.9\%)，第 2 階層では買物 (25.9\%)，業務 $(20.1 \%)$ ，第 1 階層では遊び $(57.6 \%)$, 通 学 $(54.4 \%)$, 買物 $(51.3 \%)$ が主体的交通目的である（第 3 表B）。

このことから，階層が上位の道路網ほど業務，通勤を主体とした限られた交通目的に供し，下位のそれ は通学, 買物, 遊び, それに通勤, 業務といつた多様な交通目的が主体的となつている。階層別道路網に おいて，このような交通機関，交通目的の違いはトリップ長に係つていると考えられる。つまり，徒歩， 自転車は短トリップに，自動車は長トリップにしる交通機関である。また，買物，通学，遊びに供するト リップは短距離を要求し, 逆に業務は長距離を強制する傾向にある。これらのことはとりもなおさず, 上 
位の道路網におけるトリップ長は長く，下位のそれは短いことを示している。

以上，階層別道路網の交通流の性質について比較考察した。その結果ははじめに仮定した通りである。 つまり，これは道路網の階層化システムが交通流の性質に即したものであることを実証している。しか し，道路網の連鎖線を個々に検討してみると若干交通流の性質にそぐわない部分がある。たとえば, 磐田 市の人口集中地区一天竜市の人口集中地区間を結ぶ道路は交通量が多い割にはその階層は低い。この道路 は中位中心相互を連結するものであり，はじめに仮定した交通発生・集中源としての中心地機能の配置お よび交通流の空間的パターンにそぐわない新しい現象が生じているからであると考えられる。そこに，こ の階層化システムの限界が存在しているといえる。

\section{III. 結 論}

本論において, 水流次数化システムを扡大することによつて, 複数の結節点を含む複雑な道路網の階層 化システムを提示した。それを静岡西部地域の道路網に適用して, 交通流の性質に即応しているものであ ることを実証した。しかし，このシステムは集中的交通流に供する道路網については有益であるが，分散 的交通流のそれに対しては無力であることがわかつた。また，特に交通流のデータが存在しない地域およ び国土の幹線以外の道路網を分類するのに有用な一方法であると考えられる。このシステムを用いること によつて，従来ほとんどなされていなかつた地域的道路網の連鎖線に関する分析，たとえば連鎖線間の関 係，連鎖線と地域特性の関係の規則性を計量的に分析する可能性を与えるものとなろら。

本稿を作成するに当り，東京都立大学の野間三郎教授，矢沢大二教授，中村和郎助教授ならびに建設省 道路局経済調査室の諸氏に有益な御教示々数々の御援助を賜わつた。ここに紙面をかりて深く感謝の意を 表わす次第である。

\section{参考文献}

1) WAllace, W. H. (1958) : Railroad traffic densities and patterns. A.A.A.G., 58, 352-374.

2) KISSLING, C. C. (1969) : Linkage impotance in regional highway network. Canadian Geographer, 13, 113-129.

3) U. S. Department of Transportation (1969) : 1968 National Highway Functional Classification Study Mannual. BOB. Approval No. 04-S 69009.

4) 建設省道路局経済調查室, 土木研究所道路研究室 (1972)：道路網体系の機能に関する研究.

5) 栕根 勇 (1973)：水系網の規則性. (石水照雄, 奥野隆史編：計量地理学，共立出版). 62-81.

6) HAgget, P. (1967) : Network Models in Geography. In: ChORLEy, R. J. and HAGGET, P. ed., Models in Geography. London.

7) RIDDELl, J. B. (1973) : An expansion of the HoRTON stream-ordering model to circuited transportation networks. Geographical Analysis, 5, 351-357.

8) CHRISTLlER, W. (1933) : Die zentralen Orte in Süddeutschland. Jena.

9) HAY, A. (1973) : Transport for the Space Economy. London. p. 117-118.

(1975年 8 月 30 日受理) 